\title{
A Comparative Study on the Analysis of Consumer Satisfaction in Air Services LCC and FSC
}

\author{
Yang Yong-Ho ${ }^{1}$ and Choi Hwa-Yeol ${ }^{2 *}$ \\ ${ }^{1}$ Tourism Business and Economic Research Institute, Jeju National University, 102 \\ Jejudaehakno, Jeju-si, Jeju-do 63243, South Korea \\ ${ }^{2}$ Dept. Airline Service Management School of Business, Jeju National University, 102 \\ Jejudaehakno, Jeju-si, Jeju-do 63243, South Korea \\ 1yyh5126@gmail.com, ${ }^{2}$ hwayeol@hanmail.net
}

\begin{abstract}
This study examines the effect of airline service quality (tangibility, responsiveness, personalization, and connectivity) on customer satisfaction and intention to repurchase. In particular, it is to verify whether the airline type has a moderating effect. As a result of the hypothesis, it was confirmed that tangiblity, responsiveness, personalization, and connectivity had a significant (+) effect on customer satisfaction. It was found that the responsiveness and personalization factors of Low-Cost Carriers (LCC) had a greater effect on customer satisfaction than that of Full Service Carriers (FSC).
\end{abstract}

Keywords: Service quality, Customer satisfaction, Low cost carriers, Full service carriers, Intention to repurchase

\section{Introduction}

Today's airlines are making great efforts to meet the needs of consumers. In particular, airlines are struggling to secure the competitiveness of airfare in an increasingly competitive situation. Accordingly, in many studies related to airlines, there are studies in which consumers perceive service quality perceptions of customer satisfaction and repurchase intention, loyalty, and word of mouth intention. Low-cost carriers offer limited services at cheap and simplified rates, while full service carriers focus on providing a variety of in-flight services. Most low-cost carriers operate point-to-point routes from secondary airports, while full service carriers operate hub-and-spoke models around the hub set at the primary airport. Another difference is that low-cost carriers use one type of aircraft, and full service carriers manage several types of aircraft. Many researchers and practitioners all regard service quality as a leading factor in relation to customer satisfaction and intention to repurchase. However, studies on the role of various service quality dimensions as a leading factor in customer satisfaction for low-cost airlines and large airlines show contradictory results, and the relative importance of service quality is still unclear. This study aims to investigate the moderating effect of airline types in these relationships.

\section{Theoretical background}

Article history:

Received (February 15, 2020), Review Result (March 26, 2020), Accepted (May 2, 2020) 
Service quality is measured and evaluated by the five attributes of PZB (1988) as the overall perception of customers about the company. In this study, the tangiblity of quality of service is defined as the external clue for evaluating the service to the extent that it judges physical facilities or equipment, employee appearance, communication tools, and facilities [1]. Responsiveness is defined by the ability to respond quickly to customer needs and actively provide services, and the willingness to help customers voluntarily and provide immediate service to customers [1]. Personalization means providing products, information, and services customized to the needs of users. Connectivity refers to the feeling of connecting to a world outside a specific site [2].

Full-service carriers have more passengers and have more passengers than airlines that offer lower services [3]. Kim and Lee [4] identified several dimensions of service quality that affect customer satisfaction. That is, tangency, reliability, reactivity, certainty, and empathy. Existing researches have different views on the relationship between service quality (tangibility, responsiveness, personalization, and connectivity) and customer satisfaction in the context of low-cost carriers and large carriers. It was impossible to find significant differences in the service quality of low-cost carriers and full-service carriers in relation to customer satisfaction [5]. However, Suhartanto \& Noor [6] claim that customers using fullservice carriers are more satisfied than customers using low-cost carriers. Conversely, Baker [7] found that using low-cost carriers perceives service quality higher. Rajaguru [8] said that while monetary value greatly formed satisfaction for both airline types, service quality was a leading factor in customer satisfaction and intention to act. Airline type plays a moderating role in the relationship between service quality and customer satisfaction [9].

\section{Research method}

The collection of research data for the verification of this study was conducted by requesting an online survey company. Samples were selected using the population proportional allocation method based on region and age. Online questionnaires were distributed to conduct self-written surveys, and 411 subjects who had experienced aircraft use participated in the responses. The gender composition of all respondents was 306 males (74.5\%) and 105 females (25.5\%), and $20.7 \%$ in their $20 \mathrm{~s}, 37.2 \%$ in their $30 \mathrm{~s}, 29.4 \%$ in their $40 \mathrm{~s}$, and $12.7 \%$ in their 50 s or older. The average monthly income was less than 2 million won, accounting for $11.4 \%$ of the total, $69.9 \%$ for $2-7$ million won, and $18.7 \%$ for more than 7 million won. Respondent characteristics of low-cost airlines were 150 males (73.2\%), 55 females $(26.8 \%)$, and the average monthly income was less than 2 million won, $11.7 \%$ of the total, $68.3 \%$ of $200-70$ million won, and $20 \%$ of more than 7 million won. Respondent characteristics of large airlines were 156 males (75.7\%), 50 females (24.3\%), and monthly average income was less than 2 million won, $11.2 \%$ of the total, $2-7$ million won, $71.4 \%$, and 7 million or more, $17.5 \%$.

\section{Research analysis}

\subsection{Measurement model}

A CFA was conducted to measure the validity of the six constructs (tangibility, responsiveness, personalization, and connectivity) and six constructs such as customer satisfaction and intention to repurchase. The $\chi^{2}$ value representing the overall fit of the model, the GFI and the AGFI, which represent the RMSEA and the explanatory power of the model, were analyzed, and the NFI and CFI were analyzed. The measurement models showed the 
suitability of $\chi^{2}=363.138, \mathrm{df}=209 \mathrm{p}<.05, \mathrm{GFI}=.925, \mathrm{CFI}=.968, \mathrm{NFI}=.929, \mathrm{RMR}=.020$, RMSEA $=.043$. The RMSEA was found to be less than the standard value of 0.08 , which is acceptable. In addition, since GFI, CFI, and NFI all meet the recommended standards [10], the composition of the measurement items conforms to the structural model and has explanatory power. In addition, according to the correlation analysis result and the comparison result of the AVE value, since the squared values of the correlation coefficients of the six constituent concepts are all less than 1, discriminant validity was secured.

\subsection{Configuration and metric invariance evaluation}

Hypothesis 1 relates to the causal relationship between airline service quality factors and customer satisfaction. To verify the structural causal relationship as suggested in the research model, a structural equation analysis was conducted using the SPSS-AMOS 18.0 program. As a result of verifying the suitability of the research model, the measurement model was $\chi^{2}=535.005(\mathrm{df}=310, \mathrm{p}<.0 .5), \mathrm{RMSEA}=.043, \mathrm{RMR}=.023, \mathrm{GFI}=.907, \mathrm{NFI}=.911, \mathrm{CFI}=.960$, and overall suitability is acceptable. For the hypothesis verification, the statistical significance of the standard factor load among the study model paths was analyzed. As a result of examining the significance, direction, and size of the primary path coefficient between tangibility and customer satisfaction, the $t$ value was found to be significant (beta $=.267$, $\mathrm{t}=2.949, \mathrm{p}<.05)$. Therefore, Hypothesis 1-1 was adopted. The path coefficients between responsiveness and customer satisfaction (beta $=.145, \mathrm{t}=42.579, \mathrm{p}<.05$ ) were also found to be significant, so Hypothesis 1-2 was also adopted. The path coefficient between personalization and customer satisfaction (beta=.379, $\mathrm{t}=3.166, \mathrm{p}<.05$ ), and the path coefficient between connectivity and customer satisfaction (beta=.229, $\mathrm{t}=2.794, \mathrm{p}<.05$ ) are all statistically significant. Therefore, Hypothesis 1-3 and Hypothesis 1-4 were also supported.

Table 1. Hypothesis 1 test results

\begin{tabular}{|c|c|c|c|c|c|c|}
\hline Path & $\begin{array}{c}\text { Factor } \\
\text { loading }\end{array}$ & SE & $\begin{array}{c}\text { Standardized } \\
\text { regression } \\
\text { weights }\end{array}$ & t-value & $\mathrm{p}$ & Result \\
\hline Tangibility $\rightarrow$ Customer satisfaction & .236 & .080 & .267 & 2.949 & .003 & Supported \\
\hline $\begin{array}{c}\text { Responsiveness } \rightarrow \text { Customer } \\
\text { satisfaction }\end{array}$ & .144 & .056 & .145 & 2.579 & .010 & Supported \\
\hline $\begin{array}{c}\text { Personalization } \rightarrow \text { Customer } \\
\text { satisfaction }\end{array}$ & .331 & .105 & .379 & 3.166 & .002 & Supported \\
\hline $\begin{array}{c}\text { Connectivity } \rightarrow \text { Customer } \\
\text { satisfaction }\end{array}$ & .207 & .070 & .229 & 2.794 & .003 & Supported \\
\hline
\end{tabular}

Table 2. Hypothesis 2 test results

\begin{tabular}{|c|c|c|c|c|c|c|}
\hline Path & $\begin{array}{c}\text { Factor } \\
\text { loading }\end{array}$ & SE & $\begin{array}{c}\text { Standardized } \\
\text { regression weights }\end{array}$ & t-value & $\mathrm{p}$ & Result \\
\hline $\begin{array}{c}\text { Customer satisfaction } \rightarrow \\
\text { Intention to repurchase }\end{array}$ & .981 & .068 & .912 & 14.324 & .000 & Supported \\
\hline
\end{tabular}

Hypothesis 2 relates to the causal relationship between customer satisfaction and intention to repurchase. As a result of examining the significance, direction, and size of the path 
coefficient, the $t$ value was found to be statistically significant (beta=.912, $\mathrm{t}=.14 .324, \mathrm{p}<.001$ ). Therefore, Hypothesis 2 was supported.

\subsection{Multi-group analysis results}

Prior to the analysis of parametric differences, a structural equation model was used for each group of low cost carriers, full service carriers, and the statistical significance of the fit of the model and the path coefficient between variables was tested. For low cost carriers, $\chi^{2}=347.241(\mathrm{df}=218, \mathrm{p}<.0 .5), \mathrm{RMSEA}=.056, \mathrm{RMR}=.026, \mathrm{GFI}=.866, \mathrm{NFI}=.873, \mathrm{CFI}=.948$. Suitability is generally acceptable. For full service carriers, $\chi^{2}=320.612(\mathrm{df}=218, \mathrm{p}<.0 .5)$, $\mathrm{RMSEA}=.048, \mathrm{RMR}=.026, \mathrm{GFI}=.878, \mathrm{NFI}=.882, \mathrm{CFI}=.958$. Overall, suitability was found to be acceptable. For low cost carriers, Tangibility $\rightarrow$ Customer satisfaction (beta $=.438, \mathrm{p}<.05$ ), Personalization $\rightarrow$ Customer satisfaction (beta $=.185, \mathrm{p}>.05$ ), Connectivity $\rightarrow$ Customer satisfaction (beta $=.333, \mathrm{p}<.05$ ) etc. were found to be statistically significant, but the route of Responsiveness $\rightarrow$ Customer satisfaction (beta $=.048, \mathrm{p}>.05$ ) was not significant. For full service carriers, Tangibility $\rightarrow$ Customer satisfaction (beta $=.251, \mathrm{p}<.05$ ), Responsiveness $\rightarrow$ Customer satisfaction (beta $=.290, \quad \mathrm{p}<.05)$, Personalization $\rightarrow$ Customer satisfaction (beta $=.389, \mathrm{p}<.05$ ) showed that the path was significant, and the path of Connectivity $\rightarrow$ Customer satisfaction (beta $=.132, \mathrm{p}>.05$ ) was not significant.

\subsection{Further analysis}

Hypothesis 3 relates to the difference in influence that the effect of airline service quality factors on customer satisfaction can be differentiated according to airline type. To verify this, a multiple group analysis was conducted. As a result of analysis, $\chi^{2}=643.953, \mathrm{df}=434$ in the free model and $\chi^{2}=668.221$ and $\mathrm{df}=450$ in the constraint model. Since the $\chi^{2}$ difference of the non-constrained model for the constraint model is $p=.084>\alpha=.05$, even after the constraint that the measurement weight is the same for the non-constrained model, the fit of the model does not deteriorate and cross-validity is secured between low-cost carriers and full service carriers. For each of the four paths between airline service quality and customer satisfaction, $\chi^{2}$ difference verification between constraint model and free model and critical ratio verification for differences in individual parameters were conducted. As a result of verifying the $\chi^{2}$ difference, the effect of tangibility on customer satisfaction was found to have no significant difference between business types $\left(\chi^{2}\right.$ difference $\left.=0.85, p>.05\right)$, The effect of responsiveness on customer satisfaction was found to be significantly different between companies $\left(\chi^{2}\right.$ difference $\left.=5.12, \mathrm{p}<.05\right)$. There was a difference between the types in the personal relationship-customer satisfaction $\left(\chi^{2}\right.$ difference $\left.=4.15, \mathrm{p}<.05\right)$, and connectivitycustomer satisfaction $\left(\chi^{2}\right.$ difference $\left.=4.28, \mathrm{p}<.05\right)$. According to the result of comparing the critical ratio, except for the tangibility, responsiveness $(\mathrm{t}=2.68, \mathrm{p}<.05)$, personalization $(\mathrm{t}=2.32, \mathrm{p}<.05)$, and connectivity $(\mathrm{t}=2.21, \mathrm{p}<.05)$ The causal relationship between and customer satisfaction was found to be different to airline type. As can be seen from the size and $t$ value of the path coefficient, the influence of responsiveness and personalization on customer satisfaction was greater in low-cost Carriers, and the impact of connectivity on customer satisfaction was greater in full service carriers. However, there was no significant difference in airline type in the causal relationship between tangibility and customer satisfaction. Therefore, hypotheses 4-2 and 4-3 were supported, and hypotheses 4-1 and 4-4 were rejected. 
Table 3. Hypothesis 3 test results

\begin{tabular}{|c|c|c|c|c|c|c|}
\hline \multirow[b]{2}{*}{ Path } & \multicolumn{2}{|c|}{$\chi^{2}$} & \multirow{2}{*}{$\begin{array}{c}\chi^{2} \\
\text { difference } \\
(\mathrm{df}=1)\end{array}$} & \multirow[b]{2}{*}{$\mathrm{p}$} & \multirow[b]{2}{*}{ Result } & \multirow[b]{2}{*}{$\mathrm{t}$-value } \\
\hline & Free model & $\begin{array}{l}\text { Constrai } \\
\text { nt model }\end{array}$ & & & & \\
\hline Tangibility $\rightarrow$ Customer satisfaction & \multirow{4}{*}{667.85} & 668.70 & .85 & $>.05$ & Reject & 0.97 \\
\hline Responsiveness $\rightarrow$ Customer satisfaction & & 672.98 & 5.12 & $<.05$ & Supported & 2.68 \\
\hline Personalization $\rightarrow$ Customer satisfaction & & 672.01 & 4.15 & $<.05$ & Supported & 2.32 \\
\hline Connectivity $\rightarrow$ Customer satisfaction & & 672.14 & 4.28 & $<.05$ & Reject & -2.21 \\
\hline
\end{tabular}

\section{Discussion and implications}

This study is to investigate whether airline service quality (Tangibility, Responsiveness, Personalization, Connectivity) affects customer satisfaction and whether customer satisfaction affects intention to repurchase. In this process, we examined factors that have a greater effect on customer satisfaction depending on the type of airline. In order to increase customer satisfaction, low cost carriers should focus more on responsiveness and personalization among service quality factors. Full service carriers should be operated with a focus on connectivity among service quality factors. These human service quality factors act as the strongest determinants of customer satisfaction, which is consistent with the research results of Loureiro \& Fialho [6]. In addition, it was confirmed that satisfaction with the airline leads to customers' intention to repurchase in the future. These findings are the central determinants of customer behavioral intentions, and require management's careful management of customer satisfaction. Considering Oliver's expectancy disconfirmation model [11], this result can occur because consumers' expectations about the service quality of airlines were very low when traveling with low-cost carriers, and those expectations were satisfied. Curras \& Sanchez [12] estimates that passengers flying with low-cost carriers will be able to meet these expectations at reasonable prices and at reasonable prices. The increasingly ambiguous distinction between low cost carriers and full service carriers is about the slowing effect on the satisfaction relationship of airline types. Full service carriers narrowed the gap between low cost carriers by abandoning several products offering differentiation programs.

In conclusion, this study provides useful insights into various factors affecting customer satisfaction and intention to repurchase in the context of low cost carriers and full service carriers. This study shows that two factors of service quality (external factors and human factors) have a great influence on airline customer satisfaction. Given that personalization had the greatest impact on customer satisfaction among service quality factors, airlines should pay particular attention to how to effectively improve personalized service. In particular, targeting advertisements for destinations and flight routes in consideration of past individual flight histories may be one method. It is not only limited to personalization factors, but it is also important to continuously monitor other service quality factors. Understanding customer expectations is key to helping airlines successfully fulfill these expectations and ultimately satisfy their customers.

\section{References}

[1] Parasuraman A., Zeithaml V. A., and Berry L. L., "SERVQUAL: A multiple-item scale for measuring consumer perception of service quality," Journal of Retailing, vol.64, no.1, pp.12-37, (1988) 
[2] Dholakia R. R., Zhao M., Dholakia N., and Fortin D., "Interactivity and revisits to websites: A theoretical framework," American Marketing Association. Conference Proceedings, vol.12, pp.108-114, (2001) DOI: 10.1016/j.jairtraman.2010.01.001

[3] Khan U., and Khan N., "Customer satisfaction in airline industry," International Proceedings of Economics Development \& Research, vol.76, no.12, pp.63-67, (2013) DOI: 10.7763/IPEDR.2014

[4] Kim Y. K., and Lee H. R., "Customer satisfaction using low cost carriers," Tourism Management, vol.32, no.2, pp.235-243, (2011) DOI:10.1016/j.tourman.2009.12.008

[5] Leong L. Y., Hew T. S., Lee V. H., and Ooi K. B., "An SEM-artificial-neural-network analysis of the relationships between SERVPERF, customer satisfaction and loyalty among low-cost and full-service airline," Expert Systems with Applications, vol.42, no.19, pp.6620-6634, (2015) DOI:10.1016/j.eswa.2015.04.043

[6] Suhartanto D. and Noor A, "Customer satisfaction in the airline industry: The role of service quality and price," conference paper: Asia tourism forum 2012, pp.1-9, (2012)

[7] Baker D. Mc. A., "Service quality and customer satisfaction in the airline industry: A comparison between legacy airlines and low-cost airlines," American Journal of Tourism Research, vol.2, mo.1, pp.67-77, (2013) DOI: $10.11634 / 216837861302317$

[8] Rajaguru R., "Role of value for money and service quality on behavioural intention: A study of full service and low cost airlines," Journal of Air Transport Management, vol.53, pp.114-122, (2016) DOI: 10.1016/j.jairtraman.2016.02.008

[9] Koklic M. K., Kinney M. K. and Vegelj S., "An investigation of customer satisfaction with low-cost and fullservice airline companies," Journal of Business Research, vol.80, pp.188-196, (2017) DOI: 10.1016/j.jbusres.2017.05.015

[10] Kline R. B., "Principles and practice of structural equation modeling," (2nd Edition ed.). New York: The Guilford Press, (2005)

[11] Oliver R. L., "Satisfaction: a behavioral perspective on the consumer," New York: McGraw Hill, (1997)

[12] Curras P. R. and Sanchez G. I., "Antecedents and consequences of consumer commitment in traditional and low-cost airlines," Journal of Travel \& Tourism Marketing, vol.33, no.6, pp.899-911, (2016) DOI: $10.1080 / 10548408.2016 .1251871$ 